\title{
赤外線吸収スペクトル分析法による食品包装資材 の鑑別について
}

(昭和 46 年 7 月 12 日受理)

$$
\text { 森 山繁 隆* 石 原 利 克* }
$$

\section{Identification of Packaging Material of Foods by Infrared Spectroscopy}

Shigetaka MORIYAMA and Toshikatsu ISHIHARA

(Nagoya City Health Research Institute: Hagiyamacho 1-chome, Mizuhoku, Nagoya)

In recent years plastic films have become widely used for food packaging. Further, there are many cases where different types of plastic are laminated or plastic are coated or laminated on paper or metal foil.

Among these, there are few cases that toxic additives may be present. Hence, there is a need to discriminate the types of packaging material in order to assure the safety of foods. However, with the existing transmission of IR, the absorption band might become complicated by the lamination or, in case of laminated paper or metallic foil, determination becomes impossible. Hence, a discrimination of packaging material by Attenuated Total Reflex (ATR) spectrum method was performed.

By measuring the transmission and the outer and inner sides of IR it is possible to determine the types of plastic laminated. This method was especially effective in the identification of paper or metallic foil laminated with plastic.

From the results of measurements made on about 100 packaging material of foods it was found that polyethylene was used most in contact with food, followed by polypropylene. There were no cases where polyester or polyamide was used in direct contact with foods.

(Received July 12, 1971)

\section{緒言}

食品の包装資材には従来から使用されている紙，セ口 ハン，金属およびガラスがあるが，最近発展してきたプ ラスチックならびに紙および金属䇴にこれらプラスチッ クをラミネートした包装資材が非常に広範囲に利用され ている.これらの中には可塑剤, 安定剂, 酸化防止剂な どに毒珄の䅗念のあるものがある，しかしながら行政的 な対策としては昭和 41 年10月 4 日, 厚生省告示第 434 号 による合成樹脂製の器具および容器包装の試験法の改 正, 昭和45年12月10日, 環乳第110,111号による牛乳・ 加工乳容器としてのポリェチレンの規制がなされている 程度である。

一方塩ビ食品衛生協議会では内容食品の衛生的安全性 を保持することを目的としたポジティブリスト1を作成 して自主規制につとめている. 食品の安全性を確保するためには多種多様にある包装 * 名古屋市衛生研究所： 名古屋市瑞穂区萩山町 1-11
資材の種類を鑑別する必要がある. プラスチック単体の 場合は燃焼試験などの方法"2), ()によって判明することも あり，赤外吸収スペクトルによる方法も数多く報告があ る.しかし異種のプラスチックをコートあるいはラミネ 一トしたものでは, 燃焼による方法では識別することが 困難な場合がある. そこで赤外吸収スペクトル分析法4), とくに赤外全反射吸収 (attenuated total reflaction: 以下 ATR と略記) スペクトル分析法によって, 各種食 品の包装資材の鑑別をおこなった結果について報告す る.

\section{実験方法}

機器：日本分光 IR-G 型回析格子赤外分光光度計 日本分光 ATR-4 型 多重反射装置 ATR 用 プリズム……KRS-5

(TIBr と TII の混晶)

方法：食品の包装資材を水洗乾燥して，アセトンを浸 ませた脱脂綿でよく拭った後, 透過光による吸収の測定 

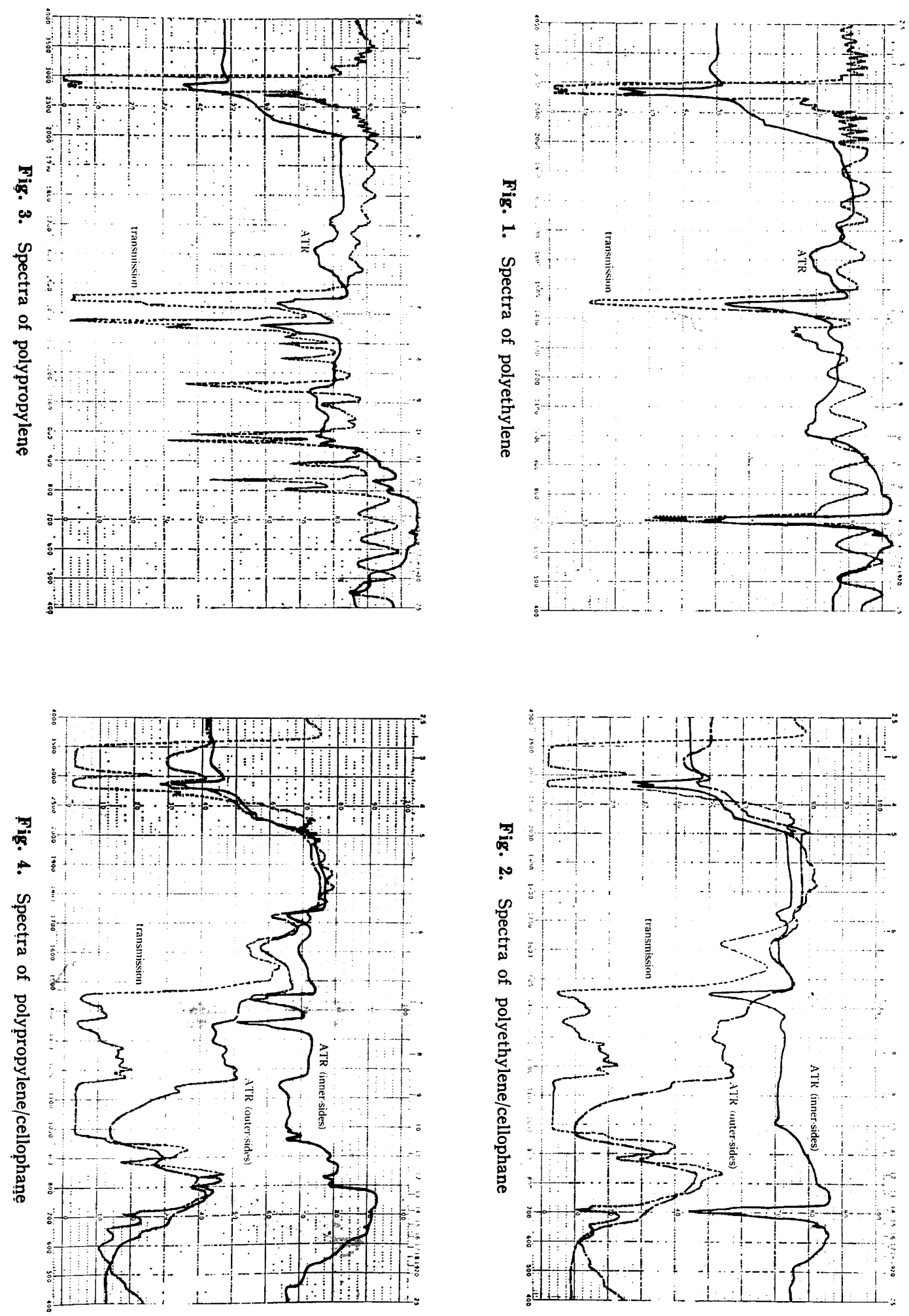

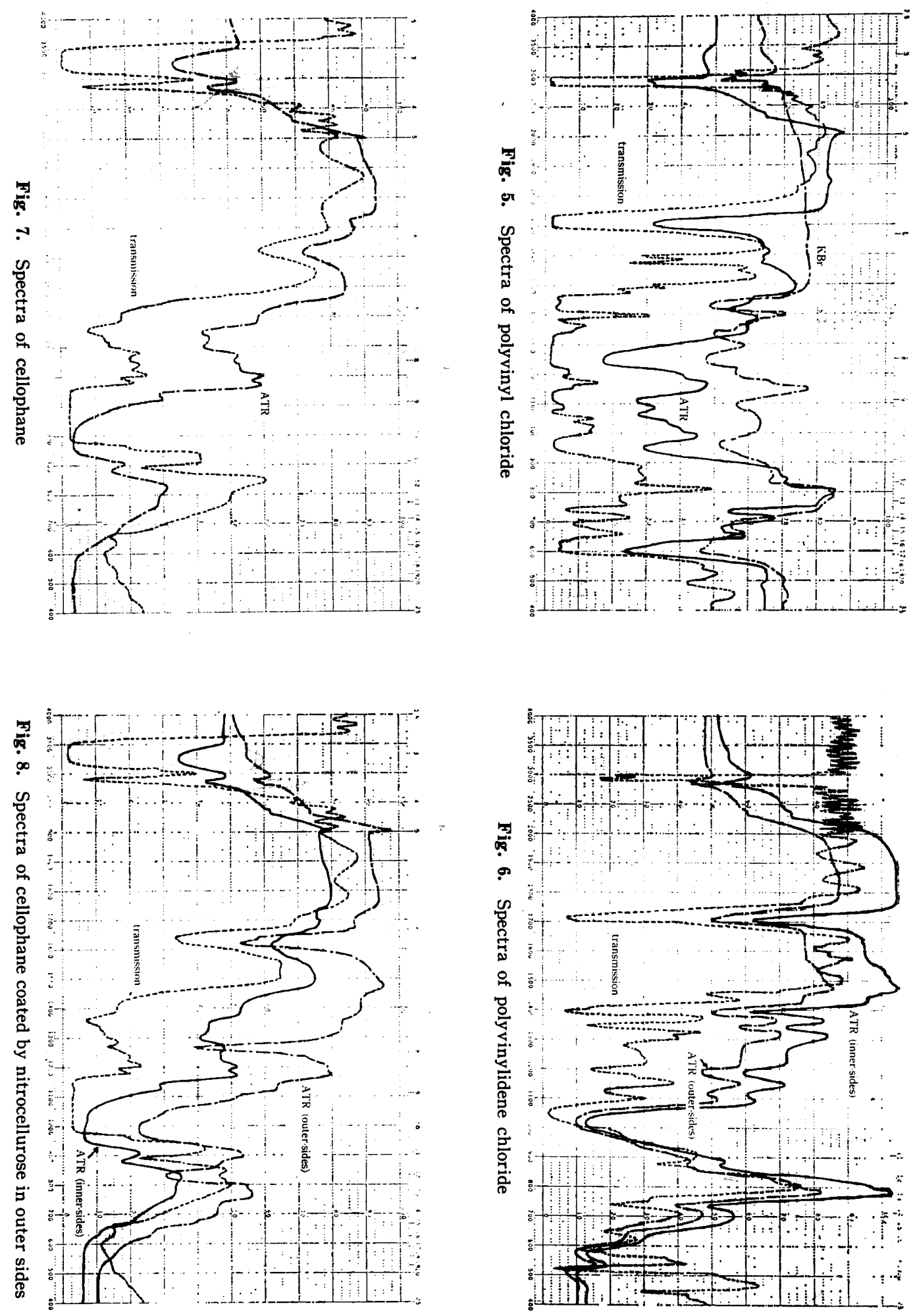

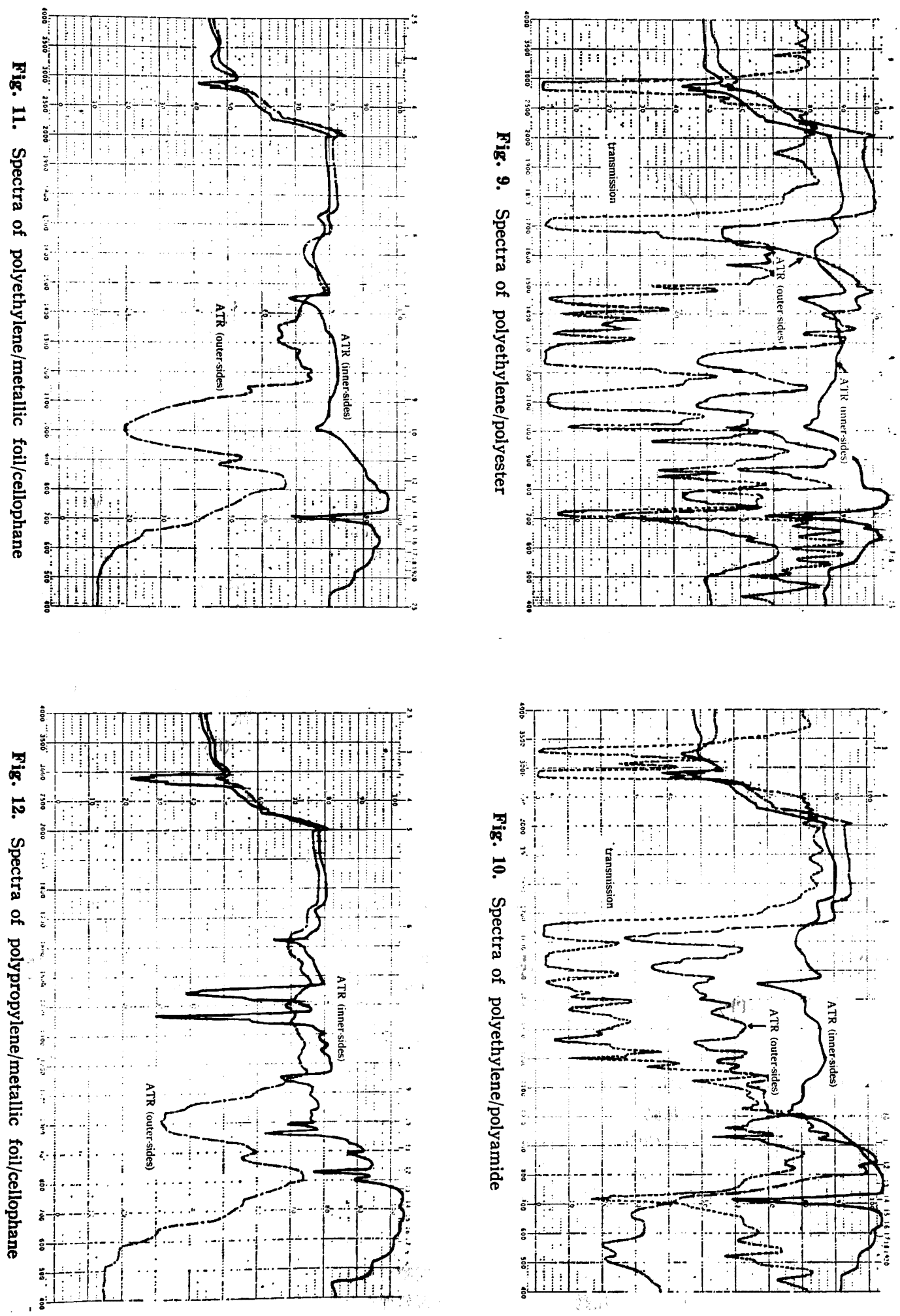


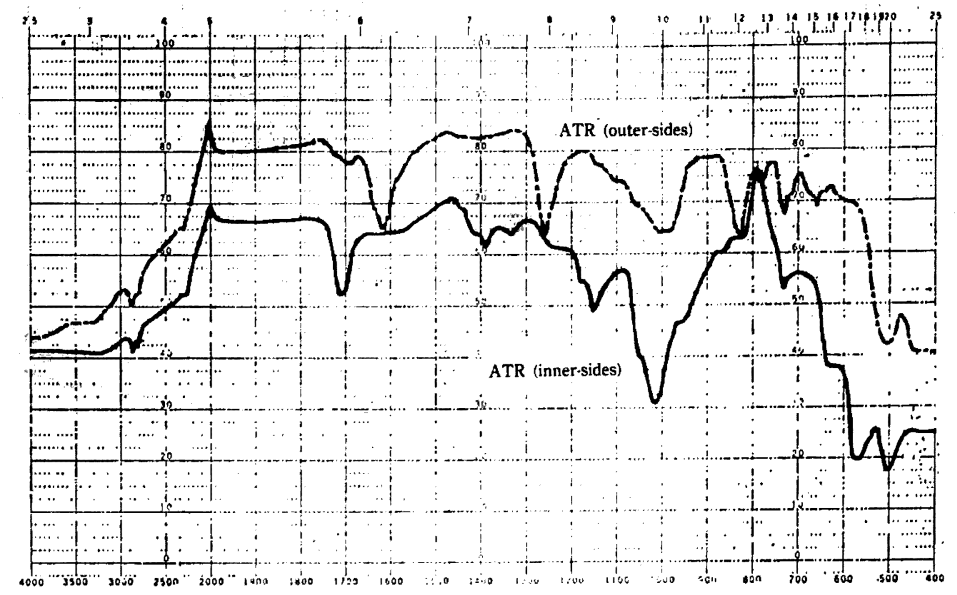

Fig. 13. Spectra of polyvinylidene chloride/metallic foil/paper/cellophane

が可能なものは透過扰よび内面，外面を ATRにより測 定した。

紙または金属箔にプラスチックをラミネートしたもの はATRによってその吸収を測定した。

\section{実験結 果}

赤外吸収スペクトルの吸収帯の䨍属は中西5), Nakamoto6) および伊保内7) 13) とよっておこなった。

1. ポリエチレン $(\mathrm{PE})$

Fig. 1

$2,850 \mathrm{~cm}^{-1}-\mathrm{CH}_{2}$-伸縮振動

$1,470,1,460 \mathrm{~cm}^{-1} \quad-\mathrm{CH}_{2}$-変角振動

$720 \mathrm{~cm}^{-1} \quad-\mathrm{CH}_{2}$-横ゆれ振動

以上のほかに著明な吸収がない，他のプラスチックと ラミネートしたもの, あるいは他のプラスチックをコ一 トしたものでは透過による吸収帯が複雑になって明瞭を 欠く場合でもATRによれば，明らかに上記の波数に吸 収帯が見られるから，明らかに判定できる (Fig. 2)。た だしATR では吸収帯がわずかながら低波数側に移動す る.

2. ポリブロピレン (PP)

Fig. 3

$2,960 \mathrm{~cm}^{-1}-\mathrm{CH}_{2}$-伸縮振動

$1,450,1,375 \mathrm{~cm}^{-1} \quad-\mathrm{CH}_{2}$-変角振動

$1,350 \mathrm{~cm}^{-1}$. - $\mathrm{CH}$ 変角振動

$1,160,840,810 \mathrm{~cm}^{-1} \quad-\mathrm{C}\left(\mathrm{CH}_{3}\right)_{2}$-骨格振動

ATR の場合は $1,450 \mathrm{~cm}^{-1}$ と $1,375 \mathrm{~cm}^{-1}$ の吸収帯 のみが明瞭に見られる. Fig. 4 はポリプロピレン/セロ ヘンの吸収である.

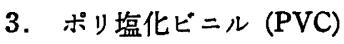

Fig. 5

$$
2,950 \sim 2,900 \mathrm{~cm}^{-1} \quad-\mathrm{CH}_{2} \text {-伸縮振動 }
$$

$1,420,1,250 \mathrm{~cm}^{-1} \quad-\mathrm{CH}_{2}$-変角振動

$960 \mathrm{~cm}^{-1} \quad \mathrm{C}-\mathrm{C}$ 伸縮振動

$695,635,610 \mathrm{~cm}^{-1} \mathrm{C}-\mathrm{Cl}$ 伸縮振動

ATR においても同波数に吸収帯が見られる。なおポ リ塩化ビニルの粉末では $1,740 \sim 1,700 \mathrm{~cm}^{-1}$ の吸収帯 はないが，フィルムとしたもの，あるいは他のプラスチ ックにコートしたものでは, この波数に透過, ATR と もにかなり強い吸収がある。 この吸収帯は $\mathrm{C}=\mathrm{O}$ に基因 するものであるから可塑剤によるものである.

4. ポリ塩化ビニリデン (PVDC)

Fig. 6

$$
\begin{array}{ll}
2,950 \sim 2,900 \mathrm{~cm}^{-1} & -\mathrm{CH}_{2} \text {-伸縮振動 } \\
1,455 \sim 1,400 \mathrm{~cm}^{-1} & -\mathrm{CH}_{2} \text {-変角振動 } \\
1,130,1,050 \mathrm{~cm}^{-1} & \mathrm{C}-\mathrm{C}^{\prime} \text {-伸縮振動 }
\end{array}
$$$$
754,650,600,520 \mathrm{~cm}^{-1} \quad \mathrm{C}^{-} \mathrm{Cl}_{2} \text { 伸縮振動 }
$$

ATR の場合にはこれらの5ち $1,455 \mathrm{~cm}^{-1}$ と 650 $\mathrm{cm}^{-1}$ の吸収が不明瞭になるが，その他の吸収帯は明膫 である。な拈 $1,720 \mathrm{~cm}^{-1}$ の吸収は PVC と同様に PVDC 本来のものではなく, 可塑剤によるものである.

5. セロハン (C)

Fig. 7

$$
\begin{aligned}
& 3,400 \sim 3,300 \mathrm{~cm}^{-1} \quad-\mathrm{OH} \text { 伸縮振動 } \\
& 1,360 \mathrm{~cm}^{-1} \quad-\mathrm{CH} \text { 変角振動 } \\
& 1,160 \sim 990 \mathrm{~cm}^{-1} \quad \text { C-O-C 伸縮振動 }
\end{aligned}
$$

このよらに非常に特徵のあるスペクトルが得られる.

このセロハンに硝化綿 (CN) をコートしたものの透過 スペクトルは Fig. 8 のようにセロ ハンの吸収帯のほか $に 1,275 \mathrm{~cm}^{-1} に=ト ロ$ 基の対称伸縮による吸収帯が現 われる: ATR では $1,275 \mathrm{~cm}^{-1}$ の二トロ基による吸収 が明瞭であるから，セロハンであるか，硝化綿によって 防湿処理をしたものであるかは明らかに判定できる. 
6. ポリエチレン/ポリエステル (PE/AL)

Fig. 9 は内面ポリエチレンの場合で，前記のように ATR によってポリェチレンは明暸である。

ポリエステルは

\begin{tabular}{|c|c|}
\hline $1,720 \mathrm{~cm}^{-1}$ & $\mathrm{C}=\mathrm{O}$ 伸縮振動 \\
\hline $1,570 \mathrm{~cm}^{-1}$ & ベンゼン核内 C-C 伸縮振動 \\
\hline \multicolumn{2}{|c|}{$1,250,1,100 \mathrm{~cm}^{-1}$} \\
\hline $1,010 \mathrm{~cm}^{-1}$ & ベンゼン核面内変角振動 \\
\hline $720 \mathrm{~cm}^{-1}$ & ベンゼン核面外変角振重 \\
\hline
\end{tabular}

これらの吸収は ATR に批いても明瞭であるから， $\mathrm{PE} / \mathrm{AL}$ の判定は容易である。

7. ポリエチレン/ナイロン (PE/PA)

Fig. 10 のように ATRによって内面のポリェチレン は明らかであり，外側のナイロンは
$3,280 \mathrm{~cm}^{-1}$
$-\mathrm{NH}$ 伸縮振動
$1,650 \mathrm{~cm}^{-1}$
アミド I $(\mathrm{C}=\mathrm{O}$ 伸縮 $)$
$1,550 \mathrm{~cm}^{-1}$
アミド II (-NH 变角)
$1,260 \mathrm{~cm}^{-1}$
アミド III (C-N 伸縮-NH 変角

混合)

$1,200 \mathrm{~cm}^{-1} \quad \mathrm{C}-\mathrm{N}$ 伸縮振動
$960,920 \mathrm{~cm}^{-1} \quad-\mathrm{CO}-\mathrm{NH}$ 面内振動

の吸収帯があり，ATR によって判定は容易である.

8. 紙・金属䈃にラミネートしたブラスチック

紙，金属箔または紙と金属䈃両者にヒートシール性， 耐油性, 耐水性, 防湿性, ガス遮断性を与えたり, 光沢 または印刷適性をよくする目的で各種のプラスチックが ラミネートされる。これらは透過法によっては測定でき ないから, ATRによったがその主なものを Fig. 11〜13 に示した，そのほか叹 Fig. 1 7 の実験のとおりであ って比較的容易に判定できる．ただし包装資材によって はラミネートの厚みが非常に薄くて ATRによる吸収に 明瞭を欠くものがあるが，判定が不可能なことはほとん どない。

9. 市販食品の包装例

収去検査および依頼検査を実施した食品のらち包装さ れたもの約 100 点の包装資材について，調査した結果は

Table 1. Packaging Material of Foods

\begin{tabular}{|c|c|c|c|c|c|}
\hline & $\begin{array}{l}\text { Number of } \\
\text { identification }\end{array}$ & $\underset{\%}{\text { Ratio }}$ & & $\begin{array}{l}\text { Number of } \\
\text { identificatin }\end{array}$ & $\underset{\%}{\text { Ratio }}$ \\
\hline Total & 106 & & & & \\
\hline PE & 6 & 5.7 & $\mathrm{PE} / \mathrm{PP}$ & 1 & 0.9 \\
\hline PP & 12 & 11.3 & PP/AL & 1 & 0.9 \\
\hline $\mathrm{C}^{*}$ & 8 & 7.5 & $\mathrm{PE} / \mathrm{P} / \mathrm{PP}$ & 1 & 0.9 \\
\hline PVC & 2 & 1.9 & $\mathrm{PE} / \mathrm{F} / \mathrm{C}^{*}$ & 9 & 8.5 \\
\hline PVDC & 2 & 1.9 & $\mathrm{PE} / \mathrm{F} / \mathrm{P} / \mathrm{C}^{*}$ & 3 & 2.8 \\
\hline $\mathrm{PE} / \mathrm{C}^{*}$ & 18 & 17.0 & $\mathrm{PE} / \mathrm{P} / \mathrm{F} / \mathrm{C}^{*}$ & 15 & 14.2 \\
\hline $\mathrm{PP} / \mathrm{C}^{*}$ & 15 & 14.2 & $\mathrm{PE} / \mathrm{F} / \mathrm{AL}$ & 6 & 5.7 \\
\hline $\mathrm{PE} / \mathrm{AL}$ & 4 & 3.8 & $\mathrm{PP} / \mathrm{F} / \mathrm{C}$ & 1 & 0.9 \\
\hline $\mathrm{PE} / \mathrm{PA}$ & 1 & 0.9 & $\mathrm{PVDC} / \mathrm{F} / \mathrm{P} / \mathrm{C}$ & 1 & 0.9 \\
\hline
\end{tabular}

C*... include cellophane coated with PVC, PVDC or CN PE.... polyethylene PP.... polypropylene $\quad$ C....cellophane $\quad$ PVC.... polyvinyl chloride PVDC....polyvinylidene chloride AL....polyester $\quad$ PA....polyamide F....metallic foil P....paper

Table-1_のとおりである.

\section{考察}

食品衛生面から包装資材を考える場合, 内容食品の腐 敗, 変敗, 食品成分の変化あるいは品質の低下を防ぐもの でなくてはならないがまた同時に包装資材から有毒,有 害な物質が食品に移行してはならない，そのような意味 で従来から多くの研究報告があり, PVC 容器からの可塑 剂, 単量体の溶出 ${ }^{14)}$,15) あるいはセロハンの耐油性 ${ }^{16)}$, 溶媒による溶出量の測定 ${ }^{17) な と ゙ て ゙ あ る 。 ま た ~ P A ~ 中 に は ~}$ 少量の単量体が存在して生物体に有害な作用を及ぼす18) といわれている.

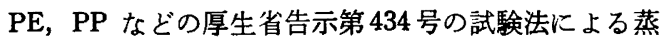
発残留物は食品包装技術便覧 ${ }^{19}$ に示されているよ5に， 低分子化合物や配合剤が $40 \mathrm{ppm}$ 程度溶出するともいわ れる.

本研究において食品に直接触れる面に使用されている のは PE がもっとも多く, PP がこれにつぎ, ついでセ ロハン，PVDC であって，野菜の熱収縮包装または店 頭に淤るプラスチック包装に PVCを使用したものが あった。

これらのらちセロハン，PP が食品に接触するものの ほとんどはビスケット，あられ，ピーナッッなど乾燥食 
品であるが，七ロハンは水蒸気透過率が大きいので, 単 独で用いられるより CN, PVC, PVDC で防湿処理し た，いわゆる防湿セロハンが多く使用される。これに反 してPP は水蒸気透過率が小さいので，あられ，浅草の りあるいは水分の揮散をきらうカステラ，パンなどに用 いられている. PE/C は即席ラーメン, 粉末清涼领料な どに用いられ，PE に紙，金属管をラミネートしたもの は即席カレー, 即席シチューなど水分含量, 脂肪含量の 多いものおよびあられ，飴菓子，ふりかけなど湿気をき ららものなど広い用途をもっている。これらのらち脂肪 含量の多いものにはPE の低分子化合物および添加剤の 溶出のないものでなければならない。

PVDC は水分の揮散, 表面の変色, 硬化防止に都合 がよいので魚肉ねり製品, チーズなどのアルミ㻴結焚を した包装に用いられるほか，ポタージュスープの包装に 紙および金属箔とラミネートして使用されている.

以上の上5に透過法之 ATR 法の併用によって, 包装, 資材の鑑別が比較的容易にできる。

総 括

1. 透過および ATRによる赤外吸収スペクトル測定 によってプラスチックの単体, コートおよびラミネート したフィルムの判別ができる.

2. 紙あるいは金属䇴にプラスチックをラミネートし たものはATRによって判定可能である.

3. 食品との接触面にはポリエチレンの使用がもうと も多く,これはポリェチレンがヒートシール性の良好な こと, 防湿性の比較的よいことによる.

しかし酸素透過率が大きいため耐油性はよくないの で, 脂肪含量の多い食品には適当でなく, ポリプロビレ ン，ポリ塩化ビニリデンの使用が望ましい．

4. ポリエステルおよびポリアミドの使用は少なく， 両者ともにヒートシール性が劣るので, 食品との接触面
にこれらを使用したものはなかった。 な扰本報の要旨は日本食品衛生学会第22回学術議演会 (昭和46年10月22日 高松市) に批いて発表.

文甫

1）加藤文夫：食品街生研究 21, 60 (1971).

2）合成楖脂工業技術研究会編：“合成樹脂便筧” p. 486 (1966) 産業図鲁.

3）厚生省編：“食品衛生閶倸法規集” p. 444-25. （1966）第一法規出版.

4）田烟米㮩：化学の領域 增刊 41, 55 (1960) 南 江堂.

5）中西香栜：赤外線吸収スベクトル（1961）南江: 堂.

6) K. Nakamoto: "Infrared Spectra of Inorganicand Coordination Compounds" p. 171 (1970). New York.

7）伊保内堅：プラスチックス 21，(7) 116 (1970).

8）伊保内贯：同上. $21(8), 117$ (1970).

9）伊保内㹂：同上. 21 (9), 113 (1970).

10）伊保内堅：同上. $21(10), 142$ (1970).

11）伊保内堅：同上. 21 (12), 106 (1970).

12）伊保内棸: 同上. 22 (1), 142 (1971).

13)- 伊保内䝨：同上. 22 (2), 109 (1971).

14）小松美博, 並木恒久, 森 文雄：食管誌。11，17 (1970).

15）沖 慶雄：有機合成化学協会誌 26, 688 (1968).

16) 小西彦市：食品の科学 6 (5), 24 (1964).

17) 岡田太郎： ジャパンフードサイェンス 5 (11), 40,

18） 日色和夫：プラスチックス 22 (5), 136 (1971).

19）日本包装技術協会編：“食品包装技術便管”p. 812 (1969) 日本生産性本部.

(1966). 